\title{
Usefulness of PET/CT in the diagnosis of recurrent or metastasized differentiated thyroid carcinoma
}

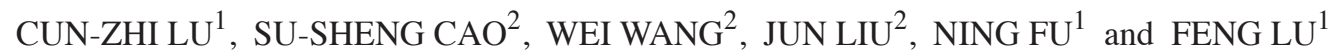 \\ Departments of ${ }^{1}$ Nuclear Medicine and ${ }^{2}$ Thyroid Surgery, Xuzhou Central Hospital, Xuzhou, Jiangsu 221009, P.R. China
}

Received October 7, 2015; Accepted February 15, 2016

DOI: $10.3892 / 01.2016 .4229$

\begin{abstract}
The aim of the present study was to determine the usefulness of the positron emission tomography/computed tomography (PET/CT) with ${ }^{18} \mathrm{~F}$-fluorodeoxyglucose (FDG) in the detection of recurrence or metastasization of differentiated thyroid carcinoma (DTC) in patients with abnormal thyroglobulin levels and negative findings on the ${ }^{131} \mathrm{I}$-diagnostic whole-body scanning (dWBS). Fifteen patients with DTC, abnormal thyroglobulin levels, and negative ${ }^{131} \mathrm{I}-\mathrm{dWBS}$ findings were scanned using the ${ }^{18} \mathrm{~F}-\mathrm{FDG}$ PET/CT. Positive diagnosis was based on postoperative histologic findings, and clinical and imaging follow-up results obtained in the subsequent 6 months. In addition, preoperative and postoperative thyroglobulin levels were compared. Using the findings of ${ }^{18}$ F-FDG PET/CT and data on confirmed positive diagnosis, sensitivity and positive predictive value (PPV) were calculated. Sensitivity and PPV of PET/CT in detecting recurrence or metastasisization of DTC were 93.30 and $91.40 \%$, respectively. Furthermore, postoperative thyroglobulin levels were markedly lower compared to the preoperative levels (respectively, $4.67 \pm 1.71$ vs. $58.53 \pm 18.34 \mathrm{ng} / \mathrm{ml}$; $\mathrm{p}<0.05$ ). PET/CT scan with ${ }^{18} \mathrm{~F}-\mathrm{FDG}$ is an informative technique for the detection of recurrent or metastasized DTC in patients with abnormal thyroglobulin levels and negative ${ }^{131} \mathrm{I}$-dWBS findings.
\end{abstract}

\section{Introduction}

The incidence of thyroid carcinoma is the highest among head and neck carcinomas. Differentiated thyroid carcinoma (DTC) accounts for $90 \%$ of thyroid cancers, with $20 \%$ of patients experiencing disease relapse, which decreases survival rates (1). A timely diagnosis of thyroid cancer recurrence is critical. Evaluation of serum thyroglobulin and ${ }^{131} \mathrm{I}$-diagnostic

Correspondence to: Dr Su-Sheng Cao, Department of Thyroid Surgery, Xuzhou Central Hospital, 199 Liberation of South Road, Xuzhou, Jiangsu 221009, P.R. China

E-mail: cssxzsy@126.com

Key words: ${ }^{18} \mathrm{~F}$-fluorodeoxyglucose positron emission tomography/ computed tomography, differentiated thyroid carcinoma, tumour recurrence, metastasization whole-body scanning (dWBS) are the most commonly employed detection techniques. However, 15-20\% of patients with abnormal thyroglobulin levels show negative findings on ${ }^{131} \mathrm{I}$-dWBS $(2,3)$. Furthermore, it is difficult to differentiate the recurrence of DTC from cicatricial tissue by computed tomography $(\mathrm{CT})$, positron emission tomography (PET), magnetic resonance imaging (MRI), or ultrasound (4). Subsequently, PET/CT has been introduced in the diagnostics of DTC, since PET/CT shows metabolic activity and anatomical abnormalities, characteristic of the tumour.

Between December 2005 and June 2013, ${ }^{18}$ F-fluorodeoxyglucose (FDG) PET/CT was utilized to diagnose 15 patients with DTC. The results identified ${ }^{18} \mathrm{~F}-\mathrm{FDG}$ PET/CT as a valuable detecting technique for the recurrence or metastasization of DTC.

\section{Materials and methods}

Patients. Fifteen patients with DTC were admitted to the Department of Nuclear Medicine of the Xuzhou Central Hospital (Xuzhou, China) between December 2005 and June 2013. There were 3 male and 12 female patients, aged 25-58 years, with a median age of 46 years (Table I). The patients were diagnosed with DTC, and underwent total or subtotal thyroidectomy.

The pathological types comprised 14 cases of papillary carcinoma and 1 case of follicular carcinoma. The patients received 1 or several courses of postoperative treatment with ${ }^{131} \mathrm{I}$ : 1 patient was treated once, 4 patients were treated twice, 6 patients were treated three times, 2 patients were treated four times, 1 patient was treated six times, and the remaining patient was treated eight times. At the follow up after the treatment, elevated levels of thyroglobulin $(>20 \mathrm{ng} / \mathrm{ml})$ and negative ${ }^{131} \mathrm{I}$-dWBS findings were present in each of these patients. Subsequently, tumour recurrence or metastasization was suspected. The patients underwent PET/CT examination. Patients continued receiving thyroidin pills following surgery, including during PET/CT, to avoid deterioration of the tumour.

${ }^{18}$ F-FDG PET/CT imaging. The Philips GXL 16 PET/CT scanning instrument (Philips Medical Systems, Inc., Cleveland, $\mathrm{OH}$, USA) was used. The patients fasted for $\geq 6 \mathrm{~h}$ prior to scanning. Strict blood glucose levels (non-diabetic patients, $<6.1 \mathrm{mmol} / \mathrm{l}$; patients with diabetes, $<8.3 \mathrm{mmol} / \mathrm{l}$ ) were maintained. The patients were intravenously administered $270-370 \mathrm{MBq}$ of 
Table I. Demographic and clinical data of 15 study patients.

\begin{tabular}{|c|c|c|c|c|c|c|c|}
\hline $\begin{array}{l}\text { Patient, } \\
\text { no. }\end{array}$ & Gender & $\begin{array}{l}\text { Age, } \\
\text { years }\end{array}$ & $\begin{array}{l}\text { Histological type } \\
\text { of the tumour }\end{array}$ & $\begin{array}{l}\mathrm{PET} / \mathrm{CT} \\
\text { diagnosis }\end{array}$ & $\begin{array}{l}\text { Surgery/follow-up } \\
\text { confirmation }\end{array}$ & $\begin{array}{c}\text { Preoperative } \\
\text { thyroglobulin, } \mathrm{ng} / \mathrm{ml}\end{array}$ & $\begin{array}{c}\text { Postoperative } \\
\text { thyroglobulin, } \mathrm{ng} / \mathrm{m}\end{array}$ \\
\hline 1 & Female & 36 & $\begin{array}{l}\text { Papillary } \\
\text { carcinoma }\end{array}$ & $\begin{array}{c}2 \text { cervical } \\
\text { lymph nodes }\end{array}$ & 2 in neck & 53.36 & 4.34 \\
\hline 2 & Female & 45 & $\begin{array}{l}\text { Papillary } \\
\text { carcinoma }\end{array}$ & $\begin{array}{c}2 \text { cervical } \\
\text { lymph nodes }\end{array}$ & 2 in neck & 34.51 & 2.47 \\
\hline 3 & Male & 33 & $\begin{array}{l}\text { Papillary } \\
\text { carcinoma }\end{array}$ & $\begin{array}{c}2 \text { cervical } \\
\text { lymph nodes }\end{array}$ & 2 in neck & 61.74 & 5.02 \\
\hline 4 & Female & 48 & $\begin{array}{l}\text { Follicular } \\
\text { carcinoma }\end{array}$ & $\begin{array}{c}4 \text { cervical } \\
\text { lymph nodes }\end{array}$ & 4 in neck & 66.85 & 5.77 \\
\hline 5 & Female & 25 & $\begin{array}{l}\text { Papillary } \\
\text { carcinoma }\end{array}$ & $\begin{array}{c}3 \text { cervical } \\
\text { lymph nodes }\end{array}$ & 2 in neck & 56.27 & 4.73 \\
\hline 6 & Female & 58 & $\begin{array}{l}\text { Papillary } \\
\text { carcinoma }\end{array}$ & $\begin{array}{c}4 \text { cervical } \\
\text { lymph nodes }\end{array}$ & 3 in neck & 72.02 & 6.08 \\
\hline 7 & Male & 55 & $\begin{array}{l}\text { Papillary } \\
\text { carcinoma }\end{array}$ & $\begin{array}{c}2 \text { cervical } \\
\text { lymph nodes }\end{array}$ & 2 in neck & 42.25 & 3.34 \\
\hline 8 & Female & 29 & $\begin{array}{l}\text { Papillary } \\
\text { carcinoma }\end{array}$ & $\begin{array}{c}2 \text { cervical } \\
\text { lymph nodes }\end{array}$ & 2 in neck & 58.13 & 4.86 \\
\hline 9 & Female & 52 & $\begin{array}{l}\text { Papillary } \\
\text { carcinoma }\end{array}$ & $\begin{array}{c}2 \text { cervical } \\
\text { lymph nodes }\end{array}$ & 2 in neck & 49.61 & 3.53 \\
\hline 10 & Female & 40 & $\begin{array}{l}\text { Papillary } \\
\text { carcinoma }\end{array}$ & $\begin{array}{l}1 \text { cervical } \\
\text { lymph node }\end{array}$ & 1 in neck & 26.68 & 1.18 \\
\hline 11 & Female & 50 & $\begin{array}{l}\text { Papillary } \\
\text { carcinoma }\end{array}$ & $\begin{array}{c}5 \text { cervical } \\
\text { lymph nodes }\end{array}$ & 4 in neck & 83.43 & 6.71 \\
\hline 12 & Female & 42 & $\begin{array}{l}\text { Papillary } \\
\text { carcinoma }\end{array}$ & $\begin{array}{c}3 \text { cervical } \\
\text { lymph nodes }\end{array}$ & 3 in neck & 92.62 & 7.29 \\
\hline 13 & Female & 52 & $\begin{array}{l}\text { Papillary } \\
\text { carcinoma }\end{array}$ & $\begin{array}{c}3 \text { cervical } \\
\text { lymph nodes }\end{array}$ & 3 in neck & 63.45 & 5.43 \\
\hline 14 & Female & 49 & $\begin{array}{l}\text { Papillary } \\
\text { carcinoma }\end{array}$ & $\begin{array}{l}3 \text { in the lung and } \\
2 \text { in the mediastinum }\end{array}$ & $\begin{array}{c}3 \text { in lung and } \\
2 \text { in mediastinum }\end{array}$ & 475.03 & - \\
\hline 15 & Male & 46 & $\begin{array}{l}\text { Papillary } \\
\text { carcinoma }\end{array}$ & Negative & 1 in neck & 46.02 & - \\
\hline
\end{tabular}

PET, positron emission tomography; CT, computed tomography.
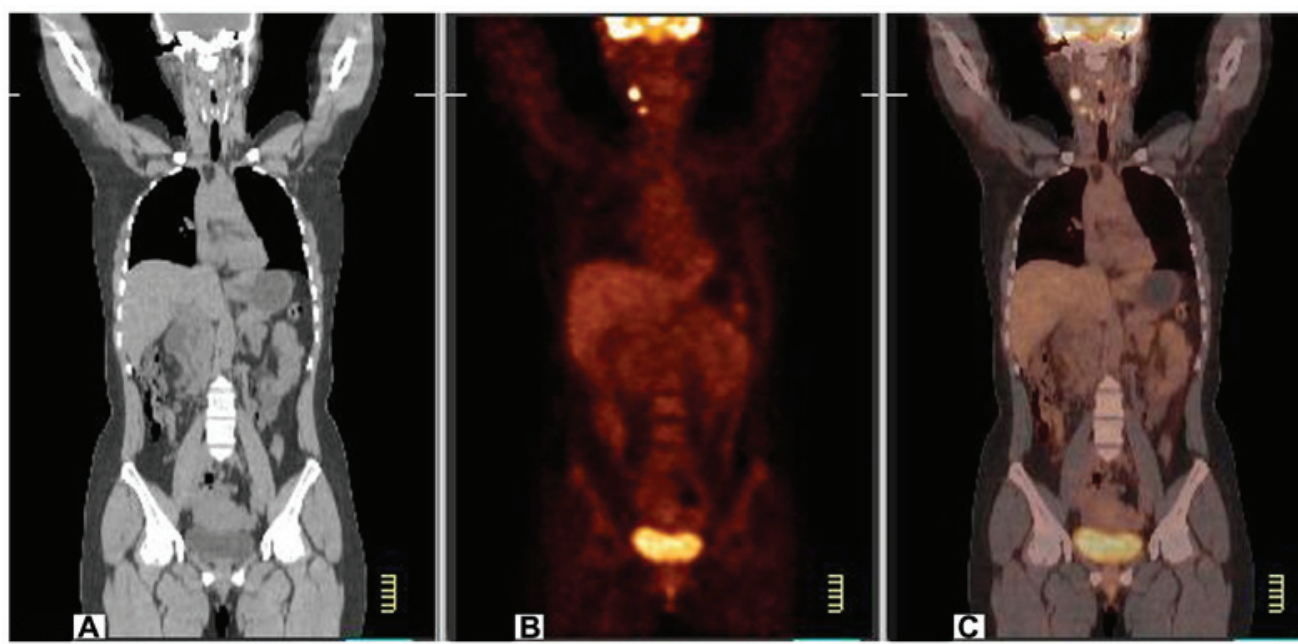

Figure 1. Cervical lymph node metastasis revealed by positron emission tomography/computed tomography (PET/CT) scanning. (A) CT imaging shows no significant neck mass. (B) PET imaging shows two lumpy abnormal radioactive concentration shadows on the right side of the neck. (C) PET/CT imaging shows two abnormal fluorodeoxyglucose hypermetabolism areas in the sternocleidomastoid region of the right side of the neck, which were considered lymph node metastases. 
${ }^{18} \mathrm{~F}-\mathrm{FDG}(4.4 \mathrm{MBq} / \mathrm{kg})$. After $60 \mathrm{~min}$ and prior to the scanning, the patients were required to empty their bladders.

Collection ranges were from the basilar part to the proximal femur. The 16-slice helical CT scanning parameters were $140 \mathrm{kV}, 320 \mathrm{~mA}$, with flat sweeping. Data were analyzed by image fusion following iterative reconstruction, obtaining coronal, sagittal and cross-sectional CT, PET and $\mathrm{PET} / \mathrm{CT}$ fusion images. The PET/CT images were reviewed independently by two radiologists who calculated a standardized uptake value of radioactive hot lesion. A standardized uptake value of $\geq 2.5$ localized in metastatic regions was considered as indicative of tumour metastasization.

Diagnostic criteria of tumour recurrence or metastasization. Based on the positive results of PET/CT scanning, the lesions located in the neck underwent surgical excision, and postoperative histopathology was carried out. The patients were monitored for their serum thyroglobulin levels for 1 month. If the lesions were located in the organs where surgical excision was problematic, the status was determined by clinical situation and the follow-up imaging results within 6 months after the initial PET/CT examination.

Data analysis. The PET/CT images were qualitatively ranked as true positive, false negative, and false positive. Sensitivity and positive predictive value (PPV) for the diagnosis of recurrence and metastasization of DTC were calculated.

Statistical analysis. The SPSS 13.0 statistical software (SPSS, Inc., Chicago, IL, USA) was used for statistical analysis. Data were presented as mean \pm standard deviation. The differences were tested using the paired t-test. $\mathrm{P}<0.05$ was considered to indicate a statistically significant difference.

\section{Results}

In 14 patients, PET/CT scanning had a sensitivity of $93.33 \%$. The 14 patients were found to have 40 tumour recurrences or metastases, of which 35 were cervical lymph node metastases (Fig. 1). The tumours were excised and were identified by postoperative pathology as being tumour metastases in 32 cases and as inflammatory changes in 3 cases. Thus, PPV comprised $91.43 \%$. In 1 patient, 5 lumps were located in the lungs and the mediastinum. No biopsy or surgical intervention were conducted in this patient. The lumps increased during the follow up for 6 months, confirming their metastatic nature.

One patient had negative PET/CT findings and developed neck lumps after 6 months of follow up, which were confirmed as tumour metastases.

A total of 13 patients with preoperative serum thyroglobulin levels of $58.53 \pm 18.34 \mathrm{ng} / \mathrm{ml}$ underwent surgery. Their postoperation serum thyroglobulin levels were $4.67 \pm 1.71 \mathrm{ng} / \mathrm{ml}$ ( $<<0.05$ vs. preoperative).

\section{Discussion}

Examination of thyroglobulin levels and ${ }^{131}$ I-dWBS following treatment is important for tumour monitoring and the detection of metastasization in DTC (5). Elevated thyroglobulin levels indicate recurrence or metastasization, resulting in ${ }^{131} \mathrm{I}$-dWBS scans being able to locate the tumour. When ${ }^{131} \mathrm{I}$-dWBS shows negative findings, B-mode ultrasound, CT, MRI, PET or other imaging techniques are used to localize recurrent or metastatic tumour. The first three methods are mainly used to locate the tumour by anatomical abnormalities, while PET reveals the tumour through metabolic abnormalities (6). Each of these techniques has its advantages and limitations. By contrast, PET/CT imaging can simultaneously reveal metabolic status and anatomical location of the lesion, thus combining the advantages of PET and CT (7). This technique is useful in difficult diagnoses, such as that for postoperative scars or nodules, which lack typical benign or malignant signs. Malignant tumours consume glucose at 10 -fold higher rates than normal or scar tissue, and this feature enables precise differential diagnosis in those cases (8). Therefore, combined functional and morphological examination during PET/CT can improve the ability to detect recurrent and metastatic tumours (9).

The diagnostic efficiency of ${ }^{18} \mathrm{~F}$-FDG PET/CT imaging in the postoperative follow up of patients with DTC depends on patient selection, sample size, thyroglobulin levels, and thyroid-stimulating hormone levels (10). Sensitivity and PPV for recurrence and metastasization of DTC range from 66 to $93.3 \%$ and from 87.5 to $100 \%$, respectively (11-13). These values are significantly higher than those achieved by B-mode ultrasound, CT, MRI, or PET alone. In the present study, sensitivity and PPV were 93.33 and $91.43 \%$, respectively, for patients with positive thyroglobulin levels and negative ${ }^{131}$ I-dWBS findings. This is in agreeement with previous findings (14-19). In such patients, metastatic tumour is more aggressive, which leads to elevation of the sensitivity of ${ }^{18}$ F-FDG PET/CT imaging. However, tumours that uptake iodine do not uptake FDG, therefore, ${ }^{18} \mathrm{~F}-\mathrm{FDG}$ PET/CT cannot fully replace ${ }^{131} \mathrm{I}$-dWBS and should not be recommended for routine screening for recurrent or metastatic DTC.

In conclusion, findings of the present study indicate that ${ }^{18} \mathrm{~F}-\mathrm{FDG}$ PET/CT imaging is an informative technique for the detection of recurrence or metastasization of DTC in patients with positive thyroglobulin levels and negative ${ }^{131} \mathrm{I}$-dWBS.

\section{References}

1. Wang E, Karedan T and Perez CA: New insights in the treatment of radioiodine refractory differentiated thyroid carcinomas: to lenvatinib and beyond. Anticancer Drugs 26: 689-697, 2015.

2. Zhang Y and Gao Z: Clinical application and progress of $\mathrm{PET} / \mathrm{CT}$ in differentiated thyroid carcinoma with positive TG and negative ${ }^{131}$ I scanning. Chin Med Device Inf 17: 8-12, 2011 (In Chinese).

3. Bertagna F, Bosio G, Biasiotto G, Rodella C, Puta E, Gabanelli S, Lucchini S, Merli G, Savelli G, Giubbini R, et al: F-18 FDG-PET/CT evaluation of patients with differentiated thyroid cancer with negative I-131 total body scan and high thyroglobulin level. Clin Nucl Med 34: 756-761, 2009.

4. Laurens ST and Oyen WJG: Value of fluorodeoxyglucose pet/computed tomography patient management and outcomes in thyroid cancer. Pet Clinics 10: 265-278, 2015.

5. Krajewska J and Jarzab B: Novel therapies for thyroid cancer. Expert Opin Pharmacother 15: 2641-2652, 2014.

6. Kim TY, Kim WG, Kim WB and Shong YK: Current status and future perspectives in differentiated thyroid cancer. Endocrinol Metab (Seoul) 29: 217-225, 2014.

7. Lauri C1, Di Traglia S, Galli F, Pizzichini P and Signore A: Current status of PET imaging of differentiated thyroid cancer with second generation radiopharmaceuticals. Q J Nucl Med Mol Imaging 59: 105-115, 2015. 
8. Tiedje V1, Schmid KW, Weber F, Bockisch A and Führer D: Differentiated thyroid cancer. Internist (Berl) 56: 153-166; quiz $167-168,2015$.

9. Kim SJ, Lee TH, Kim IJ and Kim YK: Clinical implication of F-18 FDG PET/CT for differentiated thyroid cancer in patients with negative diagnostic iodine-123 scan and elevated thyroglobulin. Eur J Radiol 70: 17-24, 2009.

10. Ma C, Xie J, Lou Y, Gao Y,Zuo S and Wang X: The role of TSH for 18F-FDG-PET in the diagnosis of recurrence and metastases of differentiated thyroid carcinoma with elevated thyroglobulin and negative scan: A meta-analysis. Eur J Endocrinol 163: $177-183,2010$.

11. Kaneko K, Abe K, Baba S, Isoda T, Yabuuchi H, Sasaki M, Hatakenaka $\mathrm{M}$ and Honda $\mathrm{H}$ : Detection of residual lymph node metastases in high-risk papillary thyroid cancer patients receiving adjuvant I-131 therapy: The usefulness of F-18 FDG PET/CT. Clin Nucl Med 35: 6-11, 2010.

12. Panareo S, Rossi R, Cittanti C, Giganti M, Prandini N, Franceschetti P,De Biasi V,Lunardon S and Feggi L: Recombinant thyrotropin stimulation improves $18 \mathrm{~F}-\mathrm{FDG}$ PET/CT sensitivity in patients with recurrent differentiated thyroid cancer. $\mathrm{J}$ Nucl Med 52 (Suppl 1): 1308, 2011.

13. Leboulleux S, Schroeder PR, Busaidy NL, Auperin A, Corone C, Jacene HA, Ewertz ME, Bournaud C, Wahl RL, Sherman SI, et al: Assessment of the incremental value of recombinant thyrotropin stimulation before 2-[18F]-Fluoro-2-deoxy-D-glucose positron emission tomography/computed tomography imaging to localize residual differentiated thyroid cancer. J Clin Endocrinol Metab 94: 1310-1316, 2009

14. Vera P, Kuhn-Lansoy C, Edet-Sanson A, Hapdey S, Modzelewski R, Hitzel A, d'Anjou J and Basuyau JP: Does recombinant human thyrotropin-stimulated positron emission tomography with [18F]fluoro-2-deoxy-D-glucose improve detection of recurrence of well-differentiated thyroid carcinoma in patients with low serum thyroglobulin? Thyroid 20: 15-23, 2010.
15. Hevrouet T, Devillers A, Cuggia M, Bernard AM, Le Jeune F, Le Dortz L, Herry JY and Garin E: Influence of rhTSH on 18 FDG uptake in a population of 42 patients with suspected recurrence of differentiated thyroid carcinoma. Med Nucl (Paris) 33: 321-330, 2009 (In French).

16. Volante M, Collini P, Nikiforov YE, Sakamoto A, Kakudo K, Katoh R, Lloyd RV, LiVolsi VA, Papotti M, SobrinhoSimoes M, et al: Poorly differentiated thyroid carcinoma: The Turin proposal for the use of uniform diagnostic criteria and an algorithmic diagnostic approach. Am J Surg Pathol 31: 1256-1264, 2007.

17. Stokkel MP, Duchateau CS and Dragoiescu C: The value of FDG-PET in the follow-up of differentiated thyroid cancer: a review of the literature. Q J Nucl Med Mol Imaging 50: 78-87, 2006.

18. Yamaga LY, Cunha ML, Wagner J, Thom AF, Daniel MM and Funari MB: Diagnostic value of positron emission tomography/computed tomography with fluorine-18 fluordeoxyglucose in patients with differentiated thyroid gland carcinoma, high thyroglobulin serum levels and negative iodine whole body scan. Arq Bras Endocrinol Metabol 51: 581-586, 2007 (In Portuguese).

19. Rivera M, Ghossein RA, Schoder H, Gomez D, Larson SM and Tuttle RM: Histopathologic characterization of radioactive iodine-refractory fluorodeoxyglucose-positron emission tomography-positive thyroid carcinoma. Cancer 113: 48-56, 2008. 